\title{
Chapels with domes on squinches in Sicily (XV-XVI century): constructive systems and structural vulnerability
}

\author{
B. Billeci ${ }^{1}$, M. Dessì ${ }^{1}$, A. M. Savia ${ }^{2}$ \& M. R. Vitale ${ }^{2}$ \\ ${ }^{1}$ Laboratory of Analysis and Conservation of Cultural Heritage, \\ Department of Architecture, Design and Urbanism, \\ Sassari University, Italy \\ ${ }^{2}$ Department of Architecture, Catania University, Italy
}

\begin{abstract}
A series of chapels with an architectural solution of great constructive meaning arose in Sicily (Italy) between the 15th and 16th century; the so called chapels with domes on squinches.

This kind of attachment between the square shape of the lower structure and the upper dome circumference is clearly distinguished from the commonly used pendentives. It represents continuity in the local constructive tradition, deriving from the Islamic and Norman heritage. Thus, we find a lot of structures with such constant elements as the squinches delimitated by recessed arches.

A few remains, situated in the western part of the island and in the Val di Noto, show masonry constructive details and structural elements, which often differ from each other, both in arrangement and materials. This circumstance, also in the light of the seismic history of this territory, draws our attention to the relation between the constructive techniques and the local context in order to assess the vulnerability level.

Therefore, this research aims:

- at analyzing these structures from the points of view of geometry, construction, materials, resistance and damage phenomena;

- at considering these buildings in the light of seismic hazard assessment;

- at defining the vulnerability of these structures in relation to conservation aims.

Keywords: dome structures, corner niches, vulnerability, typological features, risk, local materials and building system.
\end{abstract}




\section{Past research}

The domed chapels with squinches considered by the scholars to date from the mid fifteenth to the early seventeenth century; however, it has been rightly observed that the chronological extension of this phenomenon is conditioned by the uncertain and controversial dating of some examples. Still, the series of chapels remains the evidence of a particularly significant phase of the sixteenth century Sicilian architecture, in which traditional building methods are interwoven with Spanish influences and new Renaissance languages.

The label of "domed chapels with scallop squinches" was first used in 1913 by Freshfield [5], who was interested in the Byzantine cellae trichorae and to the Greek-cross churches, with a domed central space. Freshfield considers the Trinity Church in Delia and describes the solutions adopted to connect the lower square space with the circular dome. He referred to the scallop squinches system with a simple draft of St. Egidio church in Mazara and underlined its similarities with Spanish examples. However, he deemed the sixteenth-century chapels to be only the survival of earlier Arab and Byzantine building methods.

Studies conducted since the second half of the twentieth century (Scuderi [15-17]) have gradually extended the research on the domed chapels with corner squinches throughout the island. Thereby, their thorough presence in the Trapani area is referred to the late fifteenth century and the early sixteenth, while the subsequent spread in the Val di Noto lies in the sixteenth century, an historic and geographical outline that, however, is affected by the earthquakes of 1542 and 1693 that heavily marked the south-eastern Sicily architectural heritage. In these studies, the term "chapel" is generally used as to comprehend both the proper chapels and other spaces, similar to them for shapes and dimensions, such as choirs and presbyteries.

After these early studies of the phenomenon in a regional framework, new interesting research (Pagnano [14], Magnano Di San Lio [11]) has been carried on in the last part of the twentieth century, followed by a fundamental historical review (Giuffrè [8] and Nobile [12]). These last bodies of research put aside past interpretations in terms of "stylistic delay", preferring a more complete historical constructions, whereby Arab and Norman architectural languages interfere with new codes, as the result of contacts with other areas of the Mediterranean. The Sicilian season of domed chapels with corner squinches is conceived as an important experimental phase, free of the idea of any delay or derivation from other "hegemonic" areas.

The simple design of a cubic space with a corner squinches dome makes these architectures abstract and almost timeless, as already Freshfield had noticed. The large use of ashlar masonry reminds Islamic and Norman models, but altogether shows the gradual spread of other sources of knowledge and techniques, deriving from modern stereotomy (Nobile [12]). The gradual introduction of classicists themes in these simple structures is highly visible in the decorative details of niches, squinches, cornices and ribs moldings, as well as of portals and arches. This process passes through a language renewal and also affects the spatial concepts (Giuffrè [8]). 


\section{Geometric, constructive and typological features}

In the heavy experimental context of the architectural transition from the fifteenth to the sixteenth century, the linguistic contaminations and hybridisations of various models characterise odd solutions - more or less clear in the structural design - similar for the following elements.

As anticipated, the typological scheme of a cube surmounted by an Islamic dome was largely used in the Sicilian building tradition, especially in the Norman architecture. This system favoured the maintenance of the stone carving skills throughout the different Sicilian architectural seasons, particularly in the Val di Noto during this period. Still, since a real continuity is not proved, the theory of a revival seems more coherent and creditable than that of long term models and techniques (Garofalo [6], Giuffrè [8]).

The common element is the presence of a vault as its upper element. However, the chapels differ for their typological peculiarities. Thus, referring to their position, we may distinguish lateral chapels - placed on the sides of the nave - and spaces like presbyteries or choirs, which are placed in axial position, anticipating the apse. Also, they can be distinguished in relation to the solution adopted for the attachment system of the vault to the base walls. In this respect, there are various solutions like corner niches, corbels, trumpet and fan-shaped squinches. Finally, but most important for the purposes of this study, they differ for the vault building techniques, which are represented by the main models of simple hemispherical domes, sail vaults and compound vaults (like rib-vaults, cloister vaults or umbrella vaults).

As the result, there is a rich assortment of cases, all having certain recurring features on which bases we can make classifications and comparisons. Still, caution is needed. The examined buildings are often very distant from each other; both in time and space, and only in few cases one can reasonably assume direct contacts or influences between the different building sites. However, the discussion on certain recurring construction methods - so typical that one can see them as "invariant" elements in "families" of examples - helps to assess the survival of building techniques altogether with the changes introduced with the insertion of new repertoires in the traditional knowledge.

In the Trapani area the chapels are mainly placed on the sides of the nave, but there are also cases of presbyteries with domes connected with the body of the nave. For example, this is the case of the churches of S. Egidio or Carmine in Mazara.

All of the four chapels on the hyblaean area studied in the present paper are placed in axial position, so to form the choir of the single aisle. However, while the lateral position of the Cabrera chapel in the Modica church of Santa Maria di Gesù is the result of a later enlargement, the anomalous intersection between the apse and the chapel in the church of S. Antonio in Militello is the result of a nineteenth century thorough modification of the church plan.

Going back to the Trapani area and western Sicily, the attachment problem is mainly solved with a wide range of trumpet squinches. Thus, in some cases (like the Pescatori chapel in the Annunziata Church in Trapani, the Spirito Santo 
chapel in S. Maria Assunta church in Alcamo and the S. Crescenzia aedicule in S. Vito Lo Capo) the solution is represented by arches recessed and diagonally set across the angle or trumpet squinches profiled with stone mouldings. In other cases the simple shape of the corner squinches (like in the chapel of the S. Maria degli Angeli church in Trapani) is provided with shell decorations surmounted by multiple archivolts (presbyteries of S. Egidio and Carmine churches in Mazara). Also, the squinches can be associated with semicircular niches (like in the Marinai and in the Madonna chapels of the Annunziata Church in Trapani). Finally, there are also more complex solutions which involve the insertion of an octagonal tambour with niches surmounted by an half dome, generally decorated with a scallop pattern (S. Maria dello Spasimo, S. Antonio Abate and S. Francesco di Paola churches in Palermo).

The squinch system with recessed arches creates a conical surface which connects the dome to the lower orthogonal walls. The insertion of small hemispherical vaults as a base for the squinches creates a different kind of attachment, which transforms the geometry (set on a spherical surface instead of a conical one) and the conception itself of the conjunction structure. At the same time, this structure provides a safe basement for the dome and binds the below orthogonal walls. The transition from this arrangement to the hemispherical niches system, even with the introduction of an octagonal tambour, confirms a steady mastery of geometric and stereotomic rules. In the case of the Madonna chapel in the Annunziata church in Trapani, it is such knowledge and skills that allowed the construction of the small and elegant spherical pendentives which link the dome to the corner niches and the windows thick sequence in the tambour.

The chapels in S. Domenico church and in the Cathedral in Castelvetrano differ from all the other instances both in geometry and shape. In these cases, the attachment is implemented by "calotte" squinches, which spherical surface is a part of a sail vault.

The chapels in the Val di Noto area present very different solutions from the ones examined above. The corner niches and small arches system, of a Norman inspiration, disappears. Thus, the attachment is realized with diagonal projecting cornices, which, in the mentioned Cabrera chapel, are combined with short trumpet squinches. In the chapel attached to S. Antonino church in Scicli, instead, they are reduced just to simple arches. Finally, in the chapel of the S. Antonio church in Militello the system of cornices filling the corner spaces achieves a very classical language.

The building solutions to the problem of the conjunction between the base structure and the vault became a topic research and experimentation issue. The reference to coeval Spanish treatises, widely recognized by the historians (Giuffrè [8], Nobile [12]), is evident both in the research on the connection solutions and in the domes and vaults building techniques.

The execution of stone vaulted structures requires specific skills and advanced site arrangements. Both in the more common hemispherical dome model, and in the compound vaults variants, the careful ashlars engagement remains a qualifying element. In this respect, it can be submitted that the 
presence of plaster mostly is the result of subsequent interventions. The presence of such a finishing prevents us from accurately assessing the actual role of the structural ribs in the S. Crescenza aedicule. However, a possible explanation is that of a Gothic heritage or of a intentional reference to that manner. On the contrary, the Pescatori chapel represents an amazing umbrella vault, with converging ribs on a central key and curved webbing, also visible from the outside. It is an example of a traditional construction, whose structural design is a clear continuation of the Mediterranean gothic building techniques.

The cloister vaults in the Carmine and S. Egidio presbyteries in Mazara - the one probably deriving from the other - have sixteen curved surfaces cells above a double tambour (octagonal the lower one, while polygonal with sixteen sides the upper one). The cells are set between tapering toroidal ribs. The bare masonry arrangement emphasizes the sharp stone cut, the engagement skill and the effect of the thin groin ribs. These two chapels are singularly alike to other Spanish examples, like the St. Felix and Voto chapel in San Juan de la Pena monastery in Huesca, although its structural design and geometry are quite different. Observing their masonry texture, one can understand how the Sicilian instances don't have hemispherical ribbed domes, but variant forms of a "cabezera ochavada" (Nobile [12]), as described in the Vandelvira's treatise, in which the groin voussoirs forming the ribs mutually connect the adjacent curved surfaces.

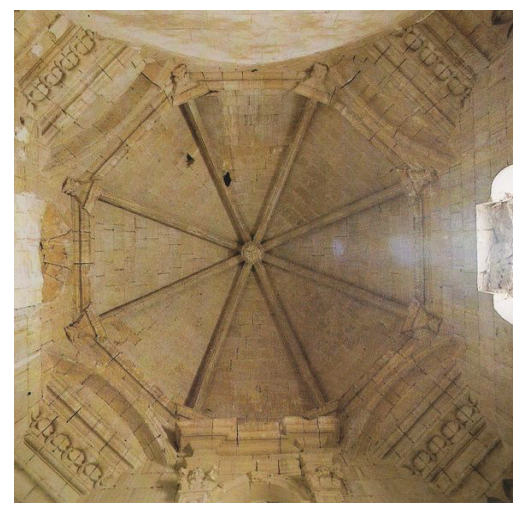

Figure 1: The chapel attached to the S. Antonino church in Scicli.

In eastern Sicily, the theme of the octagonal covering is presented with different variations and the ashlar masonry is skilfully performed, allowing a more precise assessment of the various elements structural role. The chapels in Comiso, Scicli and Militello have the same geometric and structural system, but each with specific features. As already noticed (Nobile [12]), their vaulted structure can be generally ascribed to the model of the "capilla ochavada en vuelta redonda", that is to a sail dome set upon an octagonal plant.

The Naselli chapel in S. Francesco church in Comiso is more problematical, as it is formed by a hemispherical dome and a system of ribs with a central 
keystone. While some scholars have explained such a structural singularity as a response to seismic needs, likely deriving from the 1542 earthquake (Nobile 2002), others consider it as a permanence of the Gothic manner (Giuffrè [8], Pagnano [14]). The stereotomic competence of the stone cutters - which can be seen in the ashlar arrangement as in the drum insertion on the top vault, so to form eight lunettes with splayed circular windows - rules out the idea of a structural "reinforcement", which is not supported by the overall implementation. The ribs are clearly detached from the vault and look like centrings rather than structural supporting elements. In this respect, it can be consistently submitted the hypothesis a customer influence in the choice of a design oriented to a traditional solution, as in the Cabrera chapel in S. Maria di Betlem in Modica.

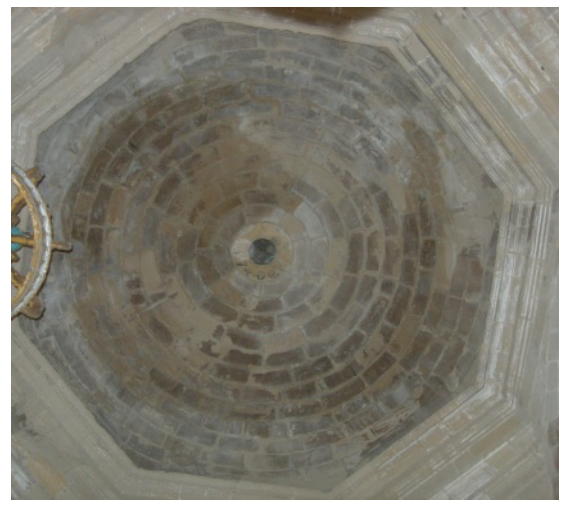

Figure 2: $\quad$ The chapel in S. Antonio church in Militello in Val di Catania.

The octagonal covering theme is more conventionally implemented in the chapel attached to the S. Antonino church in Scicli. In this case the masonry arrangement testifies a polygonal vault composed by eight curved sections. In terms of stereotomy, the chapel of the S. Antonio church in Militello is undoubtedly the most complex example. The ceiling consists of a hemispherical dome "cut" by eight lunettes. No rib fragments the stone-arranged sail vault. The uninterrupted course of the stone rows among the eight lunettes and pendentives evidences the skill of the stone-cutters. It also confirms that the persistent alternative solutions to the spherical pendentives used in the corner attachment implementation cannot be simply seen as a stylistic legacy of an out of date architectural culture, but is a fully aimed project.

\section{Building systems and seismic risk}

The issue of the domes attachment to the lower squared structure is present with a wide range of solutions in the considered cases. Thus, a structural analysis can be more easily carried out by surveying each constructive element, like domes and vaults, drums, attachments, walls and arches, etc. Moreover, also the chapel 
position in the context of the church must be regarded in the light of a seismic approach. In this respect, we can again consider the three types of chapels: isolated, lateral - mostly attached to a prior nave - and axial, having the function of presbyteries. They present different structural configurations and, consequently, different seismic behaviour.

The most widespread instances of domed chapels - autonomous spaces on the main building side - have a lower impact on the global performance. However, while the addition of a chapel to a pre-existing structure does not modify its load resistance capability, it affects the whole structural geometry, creating a more complex and asymmetrical scheme. The domed presbyteries had sometimes the function of funeral chapels and aimed at realizing a different spatial concept, in order to qualify the overall environment of the church. Even from a structural point of view, these spaces considerably affect the building resistance. Indeed, although spatially independent from the nave, they remain in axial position and wholly integrated to the rest of the building, balancing its overall construction system. It is not a coincidence that, since they enjoy a more extensive and symmetric confinement system, they also present higher domes and more prominent outside surfaces.

As previously observed, the dome structures are influenced by the Sicilian tradition of a building process based on the realization of annular courses of a same thickness. Such a practice was widely used for its simplicity and for its little need of mortar in order to bind the locally extracted limestone serial blocks. The ashlars semicircular profile - of about a $30 \mathrm{~cm}$ section - and their specific gravity confer the structures a certain stability, increased by the fact that the base is formed by continuous walls. Comparing the western and eastern instances, one can observe how the materials availability and the local building tradition affect the masonry arrangement implementation.

In the west side of Sicily, the local limestone ("tufo") is carved in small blocks of about 20x2x40 cm and arranged in low courses, having thin joints and filled with little mortar. Now, in the case of small changes in their geometry, the structures formed by these blocks have the characteristic to settle without suffering damage or cracking. The dome of the Cabrera chapel in Modica is formed by higher dressed ashlars. It presents fewer ashlar rows, arranged with wedge joints filled with mortar, unless specifically shaped elements were available. In spite of the fact that the mortar used in the two examined typologies does not result very different, its diverse arrangement in the masonry affects its stiffness in response to possible small movements. The crack pattern of the Cabrera chapel follows the joints course and evidences a stress over the mortar strength limit. In this respect, it can be submitted that domes formed by a bigger amount of smaller ashlars and thinner bed joints produce a better distribution of the loads and, before fracturing, causes some geometry modifications.

Several domical vaults with a polygonal plant tend to a circular shape due to the multitude of pseudo-rectilinear elements. From the outside, such a building syntax is shown by a polygonal extrados (like in Santa Crescenzia chapel, Naselli chapel, Pescatori chapel). In other buildings it is hidden by the protecting 
plaster, which makes it look perfectly circular (Carmine and S. Egidio churches in Mazara).

The fact that the inside of this polygonal vault is not always marked by ribs, leads us to reflect on the nature and function of these elements. The different theories on the ribs are well-known: sometimes they are a necessary support for the stability of the single vault sections and for the whole building; in other cases, they are just a decorative addition; finally, they might cooperate to the general balance, even if not basically made for this purpose. The ribs of the considered domes reveal that, depending on the circumstances, all of these instances may occur. Thus, the section of ribs of the Naselli and Pescatori chapels denounce their structural function. Now, if one wants to assess whether their contribution is fundamental for the general stability, the answer can be found only after considering their specific implementation. And this pattern must be followed for any other Sicilian ribbed vault. Indeed, whenever the rib is formed by such shaped ashlars which are integrated in the masonry vault, it obviously shares its structural function.

It would be meaningless to imagine a removal of the rib has in a similar context, since its function was relevant already in the building phase, when it served as a guideline for the courses of the squared ashlars that, being even, did not provide indications about the curved geometry of the construction. On the contrary, there is no doubt about the purely decorative function of the ribs of the $\mathrm{S}$. Egidio church. Their section is really insignificant when compared to the vault thickness. Still, as described above, they remain integrated in the vault.

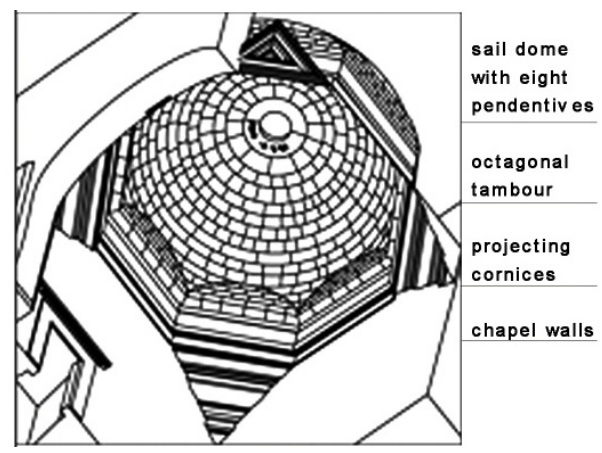

Figure 3: Axonometric scheme of the chapel in the S. Antonio church in Militello (typology with sail dome and projecting cornices.

The next significant structural element to be examined is that of the dome attachment to the lower space of the chapel. Indeed, in order to connect the square plant of the base to the dome it was necessary to generate an octagonal plan, allowing a support for the upper circular structure. The various solutions adopted to this problem have been thoroughly discussed above. We can now survey their structural response, which is usually based on the weight transfer towards the corners. Arches, shaped niches and squinches reached this effect and ensured the overall balance. 
The use of corner niches (chapels in S. Maria dello Spasimo and S. Oliva churches in Palermo, Marinai chapel in Trapani) sharply defines the connecting area and shows the structural rational hierarchies. In the case of the squinches (Pescatori chapel, Santa Maria degli Angeli chapel in S. Maria di Gesù church in Trapani), instead, such a distinction between the different structural parts is not as clear, like in the Pescatori chapel, whereby the pointed arch wedges itself between the two corner squinches areas.

Several other solutions are based on the same structural principle, referring to the skilful use of arches, like in the cases of the recessed arches and trumpet squinches discussed above. This is not the solution adopted when the conjunction is set onto projecting cornices, like in the Naselli chapel in Comiso. In this case, indeed, the octagonal tambour rests on stone cornices, whose wedge-joints ashlars denounce their role of straight-arches.

As far as the octagonal tambours are concerned, they are implemented in bare masonry, alike the medieval ones, with small windows lacking any profiling moulding. Their thickness is always considerable in order to sustain and balance the domes. The tambours masonry is implemented with different kinds of limestone ashlars or, in other cases, with rubble masonry. In the case of the two churches of Mazara, the use of a more resistant limestone is limited to the corners of the octagon, while the remaining surfaces are made of smaller and of a lower quality stones, which apparently needed to be integrated later. Although well built, the ashlar angles in the Carmine church are not efficiently connected to adjacent masonry, causing a cracking tendency.

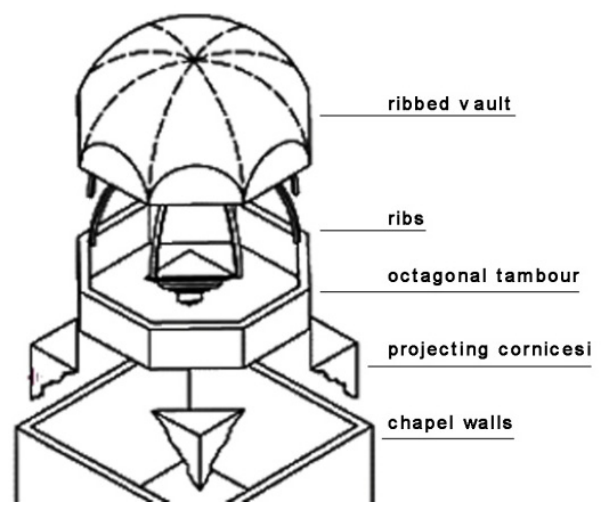

Figure 4: Exploded axonometric scheme of the chapel in the S. Antonino church in Scicli (typology with projecting cornices).

\section{Risk and vulnerability}

The building and structural characteristics discussed in the previous paragraph need to be considered in the light of the seismic history of the area, so to assess the vulnerability of the domes we are concerned. Both in eastern and western 
Sicily there is a high seismic risk, as it emerges from the current legislative and scientific classifications, consistently with the historical earthquakes catalogues.

Since the second half of the fifteenth century, a considerable amount of seismic events of a different intensity has occurred in the provinces of Catania and Messina. Particularly, the famous 1693 earthquake (the stronger earthquake ever recorded in Italy) struck all eastern towns, causing devastating damage to the buildings. It appeared with four main shocks in three days, followed by more than 1.500 aftershocks in the subsequent two years; the damaged structures suffered new movements prior their final collapse, sometimes determined also by the progressive deterioration deriving from atmospheric agents. As the historical documents show, the two earthquakes of 1726 and 1751 caused many crashes in the western cities of Palermo and Trapani, including some of the most significant buildings. Still, the seismic risk appears to be higher in eastern Sicily.

In order to assess the vulnerability of the structures we are considering, we need to consider their response to horizontal actions. It depends by position in the overall building, dimension and eventual presence of adjacent structures.

In eastern Sicily, where the buildings with axial domes prevail, the surviving chapels confirm their better response to the horizontal actions. If the structural system is sufficiently rigid, it distributes the stress along its perimeter to the outer walls. In case of horizontal forces, these churches absorb rigidly the thrusts, suffering only little deformations in either orthogonal directions, mostly if there are vaults along the perimeter.

In western Sicily - where we mostly find lateral chapels unable to benefit from the existence of adjacent structures - due to the thickness of their walls, chapels proved to be very stable organisms, also capable to provide an additional braced frame to the entire construction (e.g., in the case of the four octagonal pillars of the outer corners of the Marinai chapel in Trapani). The small dimension of the whole chapel structure contributed to their endurance, since the relatively light domes mainly followed the fate of the building, collapsing only as a consequence of the walls loss of equilibrium due to an earthquake or to the natural aging process. All of the domes of the examined chapels directly rest on short octagonal tambours of an appropriate thickness and lacking the deficiencies of long ones in responding to the thrusts coming from the dome. In fact, these short tambours are provided of a reassuring moment of inertia and capable to restraint the thrusts, while distributing the compression stress on their appropriate masonry section.

The several connecting systems with squinches (corner niches, corbels, trumpet and fan-shaped squinches etc.) are based on the same structural principle: a series of arches on the edges, with the aim to transfer the loads to this area. In the octagonal structure, the circular shape obtained with the use of these shortly projecting elements just in the connection areas allows more points of attachment and the arrangement of the first ring of the dome. The arches do not transfer loads to the corner, but to the two adjacent areas. The series of arches forms a single structure with a diversified section whose aim is to address the thrusts towards the side walls. Integrated in such a system, the corners are no longer weak points, but stabilizing elements of the structure. 


\section{Conclusions}

All the above considerations have been carried out having regard to the few remains and to the literature on the earthquakes. Still, these domes were likely the ones which had been built according to the most rational structural systems.

However, as far as a seismic hazard assessment is concerned, the following aspects are elements of reflection for subsequent searches:

1. although the position of the domed chapels in the church changes, there are always arrangements aiming at an appropriate behaviour during seismic events;

2. in spite of the specific shape, geometry and structural system of the domes, as long as the structures have limited dimensions, there are no meaningful phenomena of vulnerability;

3. the tambour is provided with an appropriate section area and a height capable to resist lateral forces; sometimes, however, there are construction inaccuracies and damage in the connecting points capable of determining kinematism in case of horizontal thrusts;

4. the several kinds of connecting elements are skilfully implemented so to resist to thrusts, unless there are failures in the supports;

5. the supporting wall structures are not particularly affected by the loads deriving from the cover and they are usually oversized;

6. the crack patterns in the domes mainly affect the joints mortar, revealing the seismic history and their capability to adapt to small geometric changes;

7. the crack patterns in the supporting walls of the domes reveal recurring damage and frequent restorations; it seems appropriate to concentrate every possible intervention to the improvement of the junctions between the orthogonal walls and the corners of the octagons with tensile resistant elements;

8. these domed churches have been variously transformed in the context of restoration, renovation and consolidation works; it's necessary to assess if these changes have caused new structural behaviours and new vulnerabilities that could be decisive in the case of future earthquakes.

\section{Acknowledgements}

The essay is the result of the joint work of the authors, however, sections 1-2 have been edited by M.R. Vitale and A. Savia, the others by B. Billeci and M. Dessì.

\section{References}

[1] Benvenuto, E.; D’agostino, S., Grimaldi, A. 1987. Structural restoration of ancient monuments subject to seismic risk: methodological problems. In: Tecnologia scienza e storia per la conservazione del costruito, Firenze: Annali della fondazione Callisto Pontello: 83-97. 
[2] Bettini, S. 1961. Tra oriente e occidente: origine della crociera d'ogive. In Saggi di storia dell'architettura in onore di Vincenzo Fasolo. In: Quaderni dell'Istituto di Storia dell'Architettura, Roma: Università di Roma, VI-VIII, 31-40: 83-92.

[3] Billeci B., The theme of dome in the sicilian architecture from XIth to XIXth century. History and conservation, doctorate thesis, University of Reggio Calabria, 2000.

[4] Escrig, F.; Valcarcel, J. 1995. Influence of constructive systems in the structural performance of ancient domes. In: Dynamics, Repairs \& Restoration. Wessex: C.A. Brebbia, B. Leftheris Editors: 179-188.

[5] Freshfield, E. H. 1913-18. Cellae trichorae and other Christian antiquities in the Byzantine provinces of Sicily with Calabria and North Africa, including Sardinia, 2 vols. London: printed privately Rixon \& Arnold.

[6] Garofalo, E. 2008. Fra Tardogotico e Rinascimento: la Sicilia sudorientale e Malta. In: La arquitectura en la Corona de Aragón entre el Gótico y el Renacimiento (1450-1550): Rasgos de unidad y diversidad. Artigrama. 23: 265-300.

[7] Giuffrè, M. 1986. Architettura e decorazione in Sicilia tra Rinascimento, Manierismo e Barocco 1463-1650. Storia architettura. 1-2: 11-40.

[8] Giuffrè, M. 1996. Architettura in Sicilia nei secoli XV e XVI: le cappelle a cupola su nicchie fra tradizione e innovazione, Storia architettura. 2: 33-48.

[9] Giuffrè, M. 2006. Le cappelle a cupola nelle chiese francescane degli Iblei. In: Francescanesimo e cultura negli Iblei: atti del convegno di studio; 2004 October 10-13; Ragusa, Modica, Comiso. Palermo: Biblioteca Francescana: 113-120.

[10] Heyman, J. 1967. On shell solutions for masonry domes. International Journal of Solids and Structures. 3, 2: 227-241.

[11] Magnano Di San Lio, E. 1996. Castelbuono capitale dei Ventimiglia, Catania: Maimone.

[12] Nobile, M. R. 2002 Un altro rinascimento. Architettura, maestranze e cantieri in Sicilia 1458-1558. Benevento: Hevelius, 2002.

[13] Nobile, M. R. 2002. La Sicilia. In: Bruschi, A., ed. Storia dell'architettura italiana. Il primo Cinquecento, Milano: Electa: 496-503.

[14] Pagnano, G. 1983. Un organismo centrico della Maniera. Rilievo della cappella di S. Antonio di Padova in Militello Val di Catania, Quaderno dell'Istituto Dipartimentale di Architettura ed Urbanistica. Catania. 13 (suppl.): 5-23.

[15] Scuderi, V. 1956. Contributo alla storia dell'architettura del Rinascimento in Trapani. In: Atti del VII Congresso nazionale di Storia dell'Architettura; 1950 September 24-30; Palermo. Palermo: a cura del Comitato presso la Soprintendenza ai Monumenti: 230-235, 290-299.

[16] Scuderi, V. 1957. Le Chiese di S. Ignazio e S. Veneranda a Mazara. Barocco siciliano inedito., in Trapani - Rassegna mensile della Provincia Anno II n. 11, 15 Novembre 1957, pp. 3-10.

[17] Scuderi, V. 1978. Arte medievale nel Trapanese. Trapani: a cura del Kiwanis international club: 83-90, 124-128. 